\title{
Structural identification of steryl alkyl ethers in marine sediments
}

\author{
Stefan Schouten $^{\mathrm{a}, *}$, Sebastiaan W. Rampen ${ }^{\mathrm{a}}$, Jan A.J. Geenevasen ${ }^{\text {b }}$, \\ Jaap S. Sinninghe Damsté ${ }^{a}$ \\ a Royal Netherlands Institute for Sea Research, Department of Marine Biogeochemistry \& Toxicology, \\ PO Box 59, 1790 AB Den Burg, Texel, The Netherlands \\ ${ }^{\mathrm{b}}$ University of Amsterdam, van't Hoff Institute for Molecular Sciences, Nieuwe Achtergracht 129, 1018 WS Amsterdam, The Netherlands
}

Available online 1 June 2005

\begin{abstract}
Steryl alkyl ethers have been reported to occur in immature marine sediments up to Cretaceous age. Here, we report their unambiguous structural identification in Holocene sediments from the Arabian Sea, Pleistocene sediments from the southeast Atlantic and a Miocene sediment from the Monterey formation through chemical degradation experiments and synthesis. We show that the main steryl alkyl ethers in sediments from the southeast Atlantic are cholest-

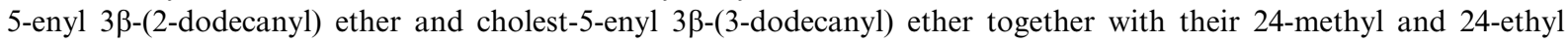

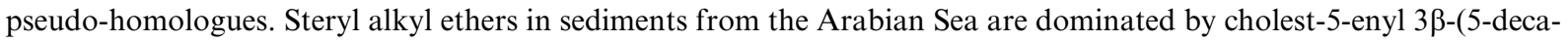
nyl) ether and cholest-5-enyl 3 $\beta$-(4-decanyl) ether together with their 24-methyl and 24-ethyl pseudo-homologues. The structures suggest that these compounds are formed by direct biosynthesis by as yet unknown marine organisms.

(c) 2005 Elsevier Ltd. All rights reserved.
\end{abstract}

\section{Introduction}

Sterols are ubiquitous compounds in eukaryotic organisms. They and their diagenetic derivatives are frequently encountered in sediments and ancient rocks. They are often used to infer the contribution of specific groups of algae, heterotrophs or higher plants (e.g., Volkman, 1986, 1999). In immature sediments, sterols are predominantly present in both free and ester-bound form. Sedimentary compounds also containing steryl moieties include steryl chlorins, where sterols are esterified with chlorophyll breakdown products through herbivory (Eckardt et al., 1992; Talbot et al., 2000).

\footnotetext{
${ }^{*}$ Corresponding author. Tel.: +31222369 565; fax: +31222 319674.

E-mail address: Schouten@nioz.nl (S. Schouten).
}

An unusual group of compounds containing steryl moieties in immature sediments are the steryl alkyl ethers. They were first reported by Boon and de Leeuw (1979) in sediments from Walvis Bay, based on comparison with a published mass spectrum of cholesteryl 1-hexadecyl ether (Funasaki and Gilbertson, 1968). Mass spectral characteristics indicate that the steryl alkyl ethers in Walvis Bay consist of $\mathrm{C}_{27}-\mathrm{C}_{29}$ sterols with 1-2 double bonds, that are ether-bound to $\mathrm{C}_{8}-\mathrm{C}_{9}$ alkyl chains. Schouten et al. (2000) reported the presence of $\mathrm{C}_{27}-\mathrm{C}_{29}$ sterols ether-bound predominantly with $\mathrm{C}_{10}$ alkyl chains in sediments from the Arabian Sea. Based on the different carbon number distributions of the free sterols and the sterol moieties of the alkyl ethers these authors suggested that the compounds represented a direct input, rather than products of secondary metabolism, as is the case for steryl chlorins (Eckardt et al., 
1992). Since steryl alkyl ethers are mainly found in sediments with high diatom inputs, Schouten et al. (2000) suggested that diatoms may be the source. Indeed, Schefuß et al. (2001) and Marlow et al. (2001) found steryl alkyl ethers in relatively high abundance in sediments deposited in highly productive upwelling areas in the southeast Atlantic. They have also been found in more ancient immature sediments. For example, they are present in immature Pleistocene to Miocene sediments from the Japan Trench (Brassell et al., 1980). Recently, their presence in immature early Cretaceous samples from the Pacific Ocean was reported (Brassell, 2003).

Despite the fact that these compounds have been regularly encountered in sediments, their exact structures have not been determined. Here, we report the detailed characterization of the structures of some of the domi- nant sedimentary steryl alkyl ethers, which are substantially different from structures previously proposed tentatively.

\section{Methods}

\subsection{Samples}

The sediments were: a Holocene sediment from the Arabian Sea, Pleistocene sediments from the southeast Atlantic and a Miocene sediment from the Monterey formation. The Arabian Sea sediment is a composite of the top $50 \mathrm{~cm}$ of a box core taken at NIOP Site 309 in the Arabian Sea taken during the 1992-1993 expedition of the R.V. Tyro in the Indian Ocean (Netherlands

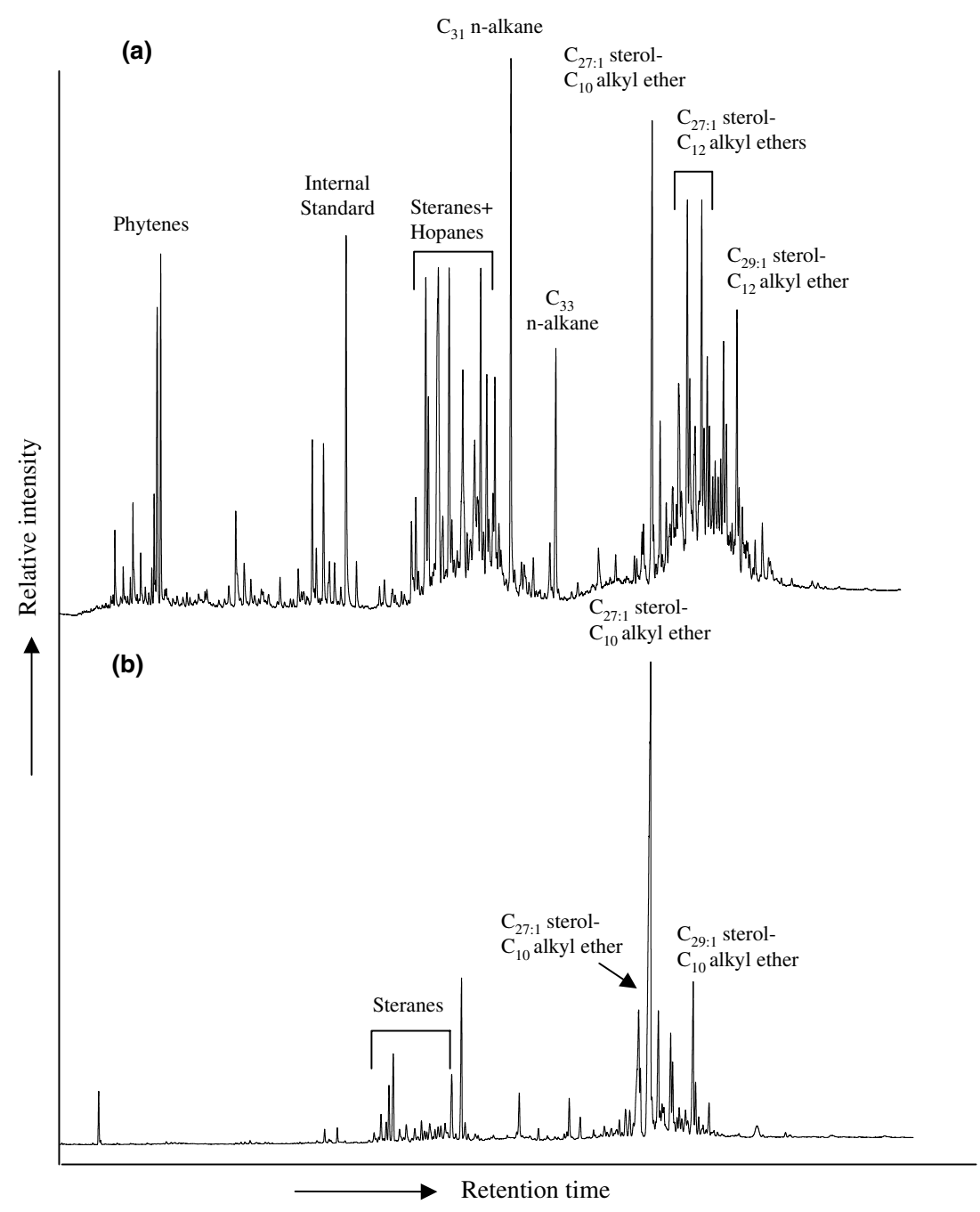

Fig. 1. Gas chromatograms of: (a) the apolar fraction of sediment extract from ODP 1084 core at 386.9 mbsf depth and (b) steryl alkyl ether fraction of the extract of the NIOP 309 sediment. Numbers with the sterol moiety of the steryl alkyl ethers indicate carbon number and number of double bonds, respectively. Number with alkyl moiety indicates number of carbon atoms. 
Indian Ocean Program; Van Weering et al., 1997). The southeast Atlantic sediments are from ODP leg 175, site 1084A at Lüderitz Bay (Schefuß et al., 2001). The Miocene sediment from the Monterey formation is sample KG-1 from the Cooperative Monterey Organic Geochemistry Study taken at an outcrop section at Naples Beach (Isaacs and Rullkötter, 2001).

\subsection{Extraction and fractionation of soluble organic matter}

Sediment samples were freeze-dried and ground using a mortar and pestle. The NIOP 309 sediment and Monterey formation sediment were Soxhlet extracted with dichloromethane (DCM)/methanol $(7.5: 1, \mathrm{v} / \mathrm{v})$ for $24 \mathrm{~h}$, whilst the ODP 1084 sample was ultrasonically extracted using DCM $(\times 3)$, methanol/DCM $(1: 1, \mathrm{v} / \mathrm{v}, \times 3)$ and methanol $(\times 3)$. The extracts were concentrated with a rotary evaporator at $30^{\circ} \mathrm{C}$. A part of each extract was separated using a column $(25 \mathrm{~cm} \times 2 \mathrm{~cm}$ i.d.; column volume $35 \mathrm{~mL}$ ) packed with alumina (activated for $2.5 \mathrm{~h}$ at $120^{\circ} \mathrm{C}$ ). Apolar fractions were obtained by elution with hexane/DCM $(9: 1, v / v)$. The apolar fraction of NIOP 309 was subsequently separated by first eluting with hexane to yield the aliphatic fraction and then eluting with hexane/DCM $(9: 1, \mathrm{v} / \mathrm{v})$ to obtain a more polar fraction which contained the steryl alkyl ethers. The apolar fraction of the extract from the Monterey formation sediment was separated using argentation thin layer chromatography with hexane as developing solvent as described by Schouten et al. (2001). The fractions which contained the sterol ethers were analysed using gas chromatography (GC) and GC-mass spectrometry (MS) and subjected to chemical degradation.

\subsection{Chemical degradation}

Fractions containing high amounts of steryl alkyl ethers were hydrogenated with $\mathrm{H}_{2} / \mathrm{PtO}_{2}$ in ethyl acetate containing a few drops of acetic acid for $1 \mathrm{~h}$ at room temperature. Acetic acid and catalyst were removed by filtration over a column filled with $\mathrm{MgSO}_{4}$ and $\mathrm{Na}_{2} \mathrm{CO}_{3}$. The fractions were analysed using GC and GC-MS to confirm the full hydrogenation of the double bonds of the steryl alkyl ethers. The hydrogenated fractions were subsequently refluxed for $1 \mathrm{~h}$ in $56 \mathrm{wt} \%\left(\right.$ in $\left.\mathrm{H}_{2} \mathrm{O}\right) \mathrm{HI}$ to cleave the ether bond of the steryl ethers. The reaction mixture was washed with water and a $5 \%$ solution of $\mathrm{NaS}_{2} \mathrm{O}_{3}$ in water and taken up in hexane. The reaction mixture was filtered over a column filled with $\mathrm{MgSO}_{4}$ to remove water. The alkyl iodides were then converted to alkyl methyl thioethers by stirring for $24 \mathrm{~h}$ with $\mathrm{NaSCH}_{3}$ in methanol. Hexane was added and the reaction mixture was washed with water and filtered over a column filled with $\mathrm{MgSO}_{4}$ to remove water. The compounds were then analyzed using GC and GC-MS.
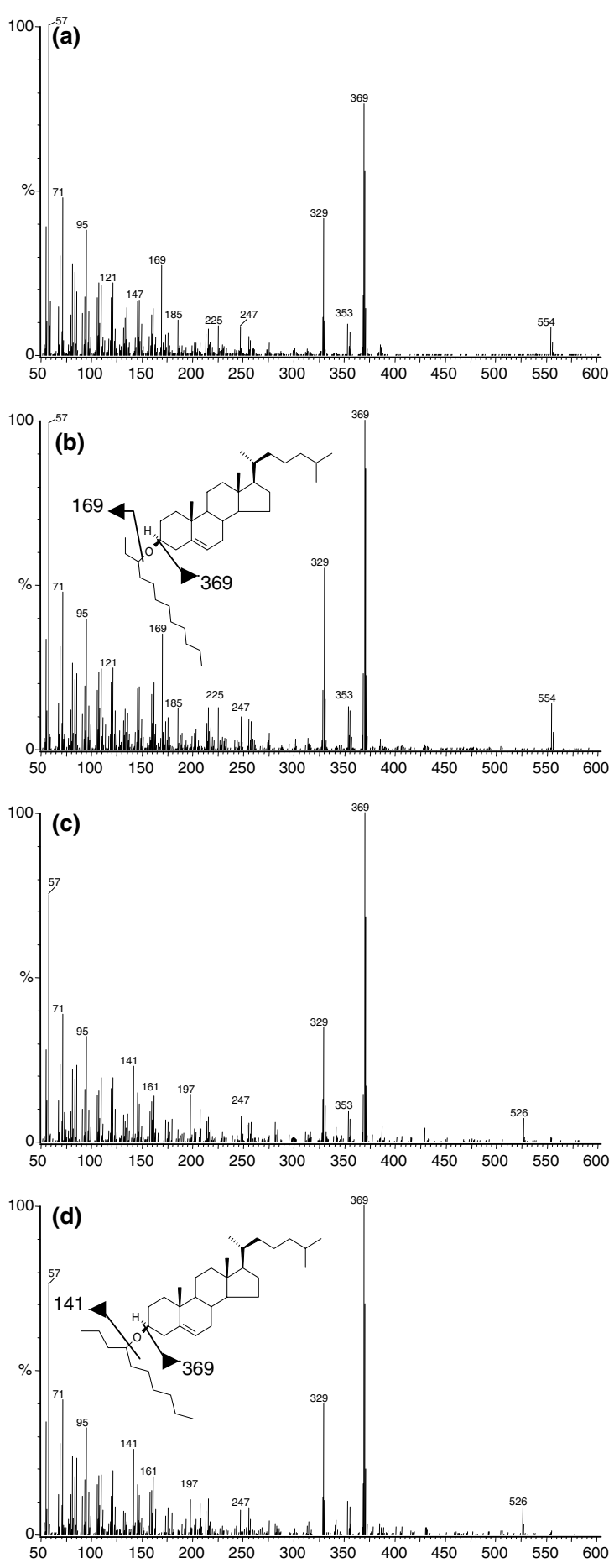

Fig. 2. Mass spectrum of: (a) cholest-5-enyl $3 \beta-\left(3^{\prime}\right.$-dodecanyl) ether in ODP 1084 sediment; (b) synthetic cholest-5-enyl 3 $\beta-\left(3^{\prime}\right.$ -

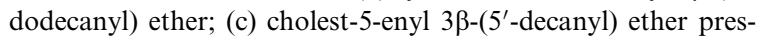
ent in the NIOP 309 sediment; (d) synthetic cholest-5-enyl $3 \beta-\left(5^{\prime}\right.$-decanyl) ether. 


\subsection{Synthesis of sterol ethers}

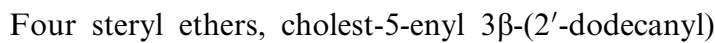
ether (Ia; for structures see Appendix), cholest-5-enyl

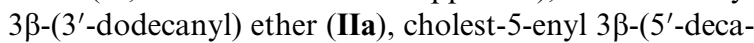

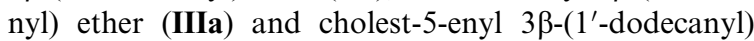
ether (IV) were synthesized as described by Bills and McDonald (1926); $60 \mathrm{mg}$ cholesterol and $350 \mathrm{mg}$ of dried kaolin ("China clay") were added to $1.4 \mathrm{~mL}$ xylene and $0.5 \mathrm{~mL}$ of either 2-dodecanol, 3-dodecanol, 5-decanol and 1-dodecanol (Daniels Fine Chemicals Ltd., Alberta, Canada). The reaction mixture was refluxed for $8 \mathrm{~h}$ and products were purified using column chromatography, i.e., they were transferred to a column of activated $\mathrm{Al}_{2} \mathrm{O}_{3}$ with a volume of $50 \mathrm{~mL}$ and eluted with $200 \mathrm{~mL}$ hexane, $150 \mathrm{~mL}$ hexane/DCM (9:1, v/v) and $150 \mathrm{~mL} \mathrm{DCM} / \mathrm{MeOH}(1: 1 \mathrm{v} / \mathrm{v})$, respectively. The products of the reaction with 5-decanol was retrieved in the last $50 \mathrm{~mL}$ of hexane/DCM fraction with a yield of $1.1 \mathrm{mg}(1.4 \%)$, whilst the products of the reactions with 1-decanol, 2-dodecanol and 3-dodecanol were recovered from the first $50 \mathrm{~mL}$ of the $\mathrm{DCM} / \mathrm{MeOH}$ eluate with yields of 4.2 and $0.9 \mathrm{mg}$, respectively (4.9 and $1.1 \%$, respectively). The reason for the different elution behaviour of the steryl alkyl ethers may be that IIIa is relatively less polar, due to the shielding of the oxygen functionality by the alkyl chain.

\section{5. $G C$ and $G C-M S$}

GC analysis and co-injection experiments were performed using a Hewlett Packard 6890 series chromatograph equipped with an on-column injector and fitted with a $25 \mathrm{~m} \times 0.32 \mathrm{~mm}$ fused silica capillary column coated with CP-Sil 5 (film thickness $0.12 \mu \mathrm{m}$ ). Helium was used as carrier gas and the oven was programmed from 70 to $130{ }^{\circ} \mathrm{C}$ at $20^{\circ} \mathrm{C} / \mathrm{min}$, followed by an increase of $4{ }^{\circ} \mathrm{C} / \mathrm{min}$ to $320^{\circ} \mathrm{C}(10 \mathrm{~min}$ hold $)$. Detection was performed with a flame ionization detector (FID).

GC-MS analysis was performed using a HewlettPackard 5890 series II chromatograph using conditions as described for GC. The column was directly inserted into the electron impact ion source of a VG - Autospec Ultima mass spectrometer, operated with a mass range of $m / z 40-800$, a cycle time of $1.8 \mathrm{~s}$ and ionization energy of $70 \mathrm{eV}$.

Table 1

Composition and relative retention times of dominant steryl alkyl ethers in synthetic products and sediments. n.d., not determined

\begin{tabular}{|c|c|c|c|c|}
\hline Sample & Steroid moiety $^{\mathrm{a}}$ & Alkyl moiety ${ }^{\mathrm{b}}$ & Position O-bond on alkyl chain & Pseudo-Kovats index ${ }^{c}$ \\
\hline \multicolumn{5}{|l|}{ Synthetic standards } \\
\hline Ia & $\mathrm{C}_{27: 1}$ & $\mathrm{C}_{12}$ & 2 & 4063 \\
\hline IIa & $\mathrm{C}_{27: 1}$ & $\mathrm{C}_{12}$ & 3 & 4035 \\
\hline IIIa & $\mathrm{C}_{27: 1}$ & $\mathrm{C}_{10}$ & 5 & 3776 \\
\hline IV & $\mathrm{C}_{27: 1}$ & $\mathrm{C}_{12}$ & 1 & 4198 \\
\hline \multicolumn{5}{|l|}{ Sediments } \\
\hline \multirow[t]{3}{*}{ NIOP 309} & $\mathrm{C}_{27: 1}$ & $\mathrm{C}_{10}$ & 5 & 3776 \\
\hline & $\mathrm{C}_{28: 1}$ & $\mathrm{C}_{10}$ & 5 & 3885 \\
\hline & $\mathrm{C}_{29: 1}$ & $\mathrm{C}_{10}$ & 5 & 3975 \\
\hline \multirow{6}{*}{$\begin{array}{l}\text { ODP } 1084 \text {, depth } 389.6 \mathrm{mbsf} \\
\quad(175-1084 \mathrm{~A}-43 \mathrm{X}-3,20-23 \mathrm{~cm})\end{array}$} & $\mathrm{C}_{27: 1}$ & $\mathrm{C}_{10}$ & 5 & 3776 \\
\hline & $\mathrm{C}_{28: 1}$ & $\mathrm{C}_{10}$ & 5 & 3887 \\
\hline & $\mathrm{C}_{29: 1}$ & $\mathrm{C}_{10}$ & 5 & 3977 \\
\hline & $\mathrm{C}_{27: 1}$ & $\mathrm{C}_{12}$ & 3 & 4039 \\
\hline & $\mathrm{C}_{28: 1}$ & $\mathrm{C}_{12}$ & 3 & 4146 \\
\hline & $\mathrm{C}_{29: 1}$ & $\mathrm{C}_{12}$ & 3 & 4252 \\
\hline \multirow{6}{*}{$\begin{array}{l}\text { ODP } 1084 \text {, depth } 34.7 \mathrm{mbsf} \\
\quad(175-1084 \mathrm{~A}-5 \mathrm{H}-3,20-23 \mathrm{~cm})\end{array}$} & $\mathrm{C}_{27: 1}$ & $\mathrm{C}_{8}$ & n.d. & 3608 \\
\hline & $\mathrm{C}_{27: 1}$ & $\mathrm{C}_{9}$ & n.d. & 3686 \\
\hline & $\mathrm{C}_{27: 1}$ & $\mathrm{C}_{10}$ & n.d. & 3790 \\
\hline & $\mathrm{C}_{27: 1}$ & $\mathrm{C}_{11}$ & n.d. & 3834 \\
\hline & $\mathrm{C}_{27: 1}$ & $\mathrm{C}_{11}$ & n.d. & 3855 \\
\hline & $\mathrm{C}_{27: 1}$ & $\mathrm{C}_{11}$ & n.d. & 3869 \\
\hline \multirow[t]{3}{*}{ Monterey Fm. KG-1 } & $\mathrm{C}_{27: 1}$ & $\mathrm{C}_{10}$ & n.d. & 3725 \\
\hline & $\mathrm{C}_{28: 1}$ & $\mathrm{C}_{10}$ & n.d. & 3930 \\
\hline & $\mathrm{C}_{29: 1}$ & $\mathrm{C}_{10}$ & n.d. & 4162 \\
\hline
\end{tabular}

\footnotetext{
${ }^{a}$ Numbers indicate number of carbon atoms and number of double bonds.

b Number indicates number of carbon atoms.

${ }^{c}$ Determined on a CPSil 5 column using the retention times of $\mathrm{C}_{38}$ and $\mathrm{C}_{40} n$-alkanes with pseudo-Kovats indices of 3800 and 4000 , respectively.
} 


\subsection{Nuclear magnetic resonance spectroscopy}

${ }^{1} \mathrm{H}$ NMR spectra were obtained at $25^{\circ} \mathrm{C}$ with a Varian Unity Inova spectrometer, operating at $500 \mathrm{MHz}$, equipped with a $5 \mathrm{~mm}$ pulsed field gradient indirect detection probe. Chemical shifts in ppm were determined relative to the solvent signal $\left({ }^{1} \mathrm{H}\right.$ in $\left.\mathrm{CDCl}_{3}\right)$ and converted to the TMS scale using $\delta_{\mathrm{CHCl}}=7.24 \mathrm{ppm}$ for proton and $77.0 \mathrm{ppm}$ for carbon. The ${ }^{2} \mathrm{H}$ resonance of $\mathrm{CDCl}_{3}$ was used for field-frequency lock. Typical proton acquisition parameters were: sweep width of $8 \mathrm{kHz}$, relaxation delay of $2,2.5 \mathrm{~s}$ acquisition time and a pulse width of $2.0 \mu$ s where the $90^{\circ}$ flip angle corresponds to $4.25 \mu \mathrm{s}$.

Carbon experiments were carried out on a $5 \mathrm{~mm}$ pulsed field gradient switchable broadband probe. The

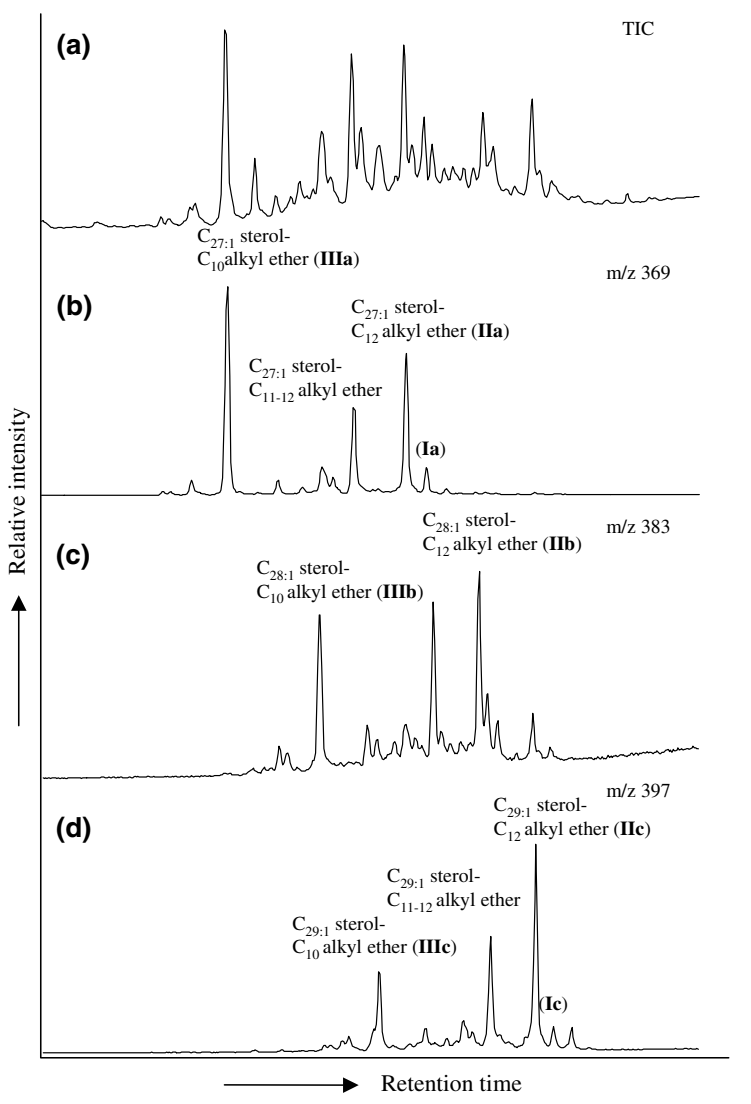

Fig. 3. Partial total ion chromatogram (a) and mass chromatograms: (b) $m / z 369$; (c) $m / z 383$; (d) $m / z 397$ of the apolar fraction isolated from Pleistocene ODP site 1084 sediment at 386.9 mbsf $(175-1084 \mathrm{~A}-43 \mathrm{X}-3,20-23 \mathrm{~cm})$ showing the distribution of steryl alkyl ethers with $\mathrm{C}_{27}, \mathrm{C}_{28}$ and $\mathrm{C}_{29}$ sterol moieties, respectively. Structure numbers refer to structures shown in Appendix. Numbers with the sterol moiety of the steryl alkyl ethers indicate carbon number and number of double bonds, respectively. Number with alkyl moiety indicates number of carbon atoms. conditions used were: sweep width $27560 \mathrm{~Hz}$, relaxation delay $3,1.3 \mathrm{~s}$ acquisition time and a pulse width of $4.0 \mu \mathrm{s}$ where the $90^{\circ}$ flip angle corresponds to $7 \mu \mathrm{s}$. Proton decoupling was performed with WALTZ-16 modulation during acquisition.

\section{Results and discussion}

\subsection{Occurrence and distribution of $C_{27}-C_{29}$ steryl alkyl ethers}

The apolar fractions from Pleistocene sediments from ODP site 1084 contained relatively high amounts of steryl alkyl ethers (e.g., Fig. 1a) as reported previously (Schefuß et al., 2001). Their mass spectra (e.g., Fig. 2a) reveal that they predominantly consist of $\mathrm{C}_{27}-\mathrm{C}_{29}$ steroid moieties with one double bond, ether-bound to

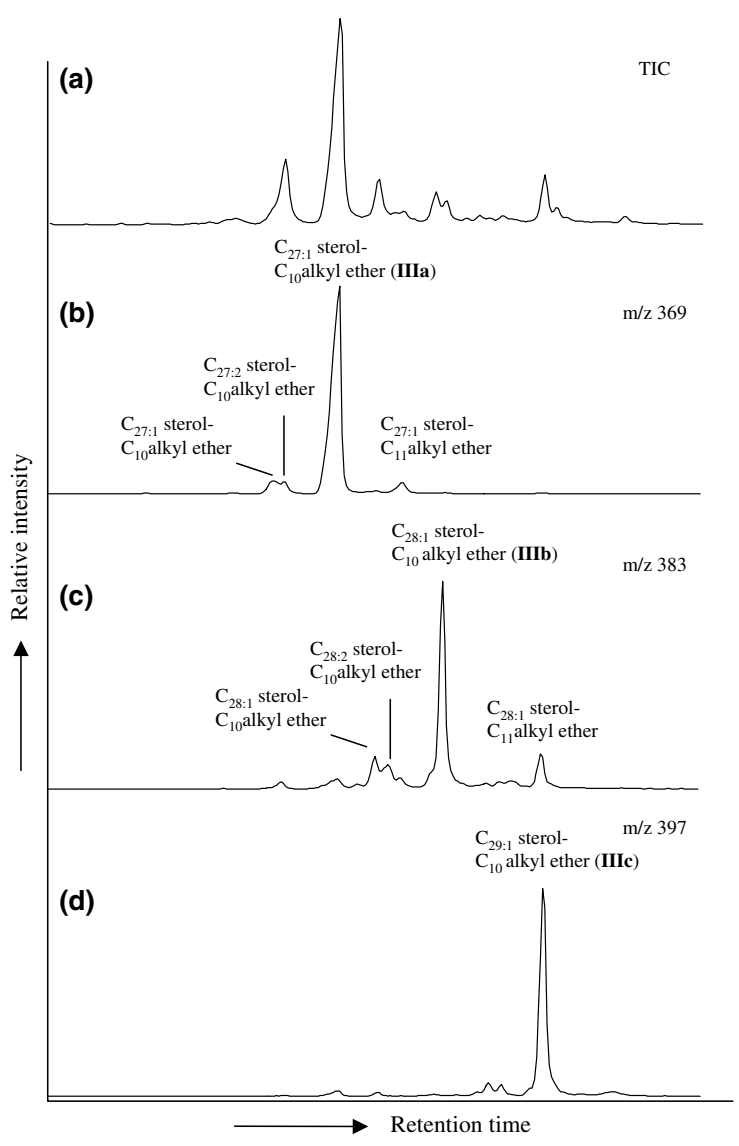

Fig. 4. Partial total ion chromatogram (a) and mass chromatograms: (b) $\mathrm{m} / \mathrm{z} 369$; (c) $\mathrm{m} / \mathrm{z} 383$; (d) $\mathrm{m} / z 397$ of the steryl alkyl ether fraction of Holocene NIOP site 309 sediment showing the distribution of steryl alkyl ethers with $\mathrm{C}_{27}, \mathrm{C}_{28}$ and $\mathrm{C}_{29}$ sterol moieties, respectively. Structure numbers refer to structures shown in Appendix. 
$\mathrm{C}_{8}-\mathrm{C}_{12}$ alkyl chains (Table 1). Mass chromatograms of $m / z 369,383$ and 397 revealed the distribution of ethers with $\mathrm{C}_{27}, \mathrm{C}_{28}$ and $\mathrm{C}_{29}$ sterol moieties, respectively (e.g., Fig. 3) and showed that at a depth of $389.6 \mathrm{mbsf}$, they are dominated by $\mathrm{C}_{27}-\mathrm{C}_{29}$ steroid moieties ether-bound to $\mathrm{C}_{10}$ or $\mathrm{C}_{12}$ alkyl chains.

The Holocene NIOP 309 sediment contained relatively high amounts of $\mathrm{C}_{27}-\mathrm{C}_{29}$ steryl ethers with a decyl moiety (Fig. 1b), as described previously for other Arabian Sea sediments (Schouten et al., 2000). Mass spectral analysis revealed that the dominant steryl alkyl ether consists of a cholesteryl moiety ether-bound to a $\mathrm{C}_{10}$ alkyl chain (Fig. 2c). Mass chromatograms of $m / z$ 369, 383 and 397 (Fig. 4) revealed that the steryl alkyl ethers are mainly composed of $\mathrm{C}_{27}-\mathrm{C}_{29}$ steroid moieties etherbound to a $\mathrm{C}_{10}$ alkyl chain.

Steryl alkyl ethers are present in relatively low abundance in a Miocene sediment from the Monterey formation. Mass chromatography revealed that, like the Arabian Sea, they are mainly composed of $\mathrm{C}_{27}-\mathrm{C}_{29}$ steroid moieties ether-bound to a $\mathrm{C}_{10}$ alkyl moiety (Fig. 5).

\subsection{Chemical degradation}

To elucidate the structures of the sterol ethers, chemical degradation experiments were performed. Fractions

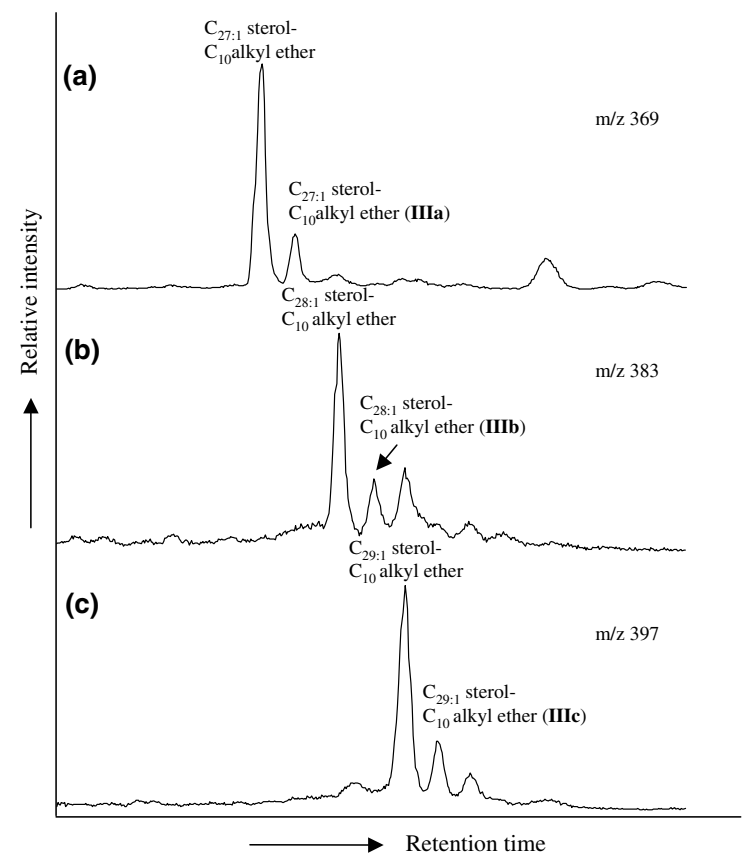

Fig. 5. Mass chromatograms of: (a) $\mathrm{m} / \mathrm{z} 369$; (b) $\mathrm{m} / \mathrm{z} 383$; (c) $\mathrm{m} / \mathrm{z}$ 397 of the steryl alkyl ether fraction from Miocene Monterey formation sediment showing the distribution of steryl alkyl ethers with $\mathrm{C}_{27}, \mathrm{C}_{28}$ and $\mathrm{C}_{29}$ sterol moieties, respectively. Structure numbers refer to structures shown in Appendix. of sediment extracts containing high amounts of steryl alkyl ethers from the NIOP 309 and ODP 1084 were hydrogenated and refluxed with HI to cleave the ether bonds. Hydrogenation was performed prior to HI-cleavage as steroids containing double bonds undergo carbon skeleton rearrangements under the strongly acidic conditions during $\mathrm{HI}$ treatment. The released alkyl iodides were reacted with $\mathrm{NaSCH}_{3}$ to replace the iodine atoms with a methylthio-group. Methyl thioethers yield characteristic fragments during mass spectrometric analysis, enabling identification of the original ether bond position (e.g., Kohnen et al., 1991; Schouten et al., 1998).

GC-MS analysis of the fraction from the NIOP 309 sterol alkyl ether fraction revealed, after chemical degradation, the presence of two groups of methyl thioethers: $\mathrm{C}_{27}-\mathrm{C}_{29}$ steroids containing one methylthio-group and $\mathrm{C}_{10}$ alkyl chains containing one methylthio-group (Fig. 6a). Comparison of relative retention times and mass spectra of the methyl thiosteroids with those of authentic standards (Kohnen et al., 1991) revealed that they predominantly consist of $\mathrm{C}_{27}-\mathrm{C}_{29}$ $3 \alpha$ - and $3 \beta$-methylthio- $5 \alpha(\mathrm{H})$-steranes with $3 \beta$-methylthiosteranes in higher abundance. This confirms that, as expected, the steryl moieties consist of regular $\mathrm{C}_{27}$ $\mathrm{C}_{29}$ sterols with one double bond in the steroid carbon skeleton, being ether-bound at C-3 to the alkyl chain in the $\beta$-stereoisomeric configuration. The minor amounts of $3 \alpha$-methylthiosteranes may reflect an enhanced Sn1 pathway under the strong acidic conditions during the HI degradation, which may have generated $3 \alpha$-iodidosteranes and $3 \beta$-iodidosteranes. The composition of the methylthioalkanes, the second group of products released during chemical degradation of the steryl alkyl ethers, was, however, surprising (Fig. 6a). Mass spectral analysis revealed that the dominant methylthioalkane was 5-methylthiodecane with minor amounts of 4-methylthiodecane and not 1-methylthiodecane as might have been expected from previous tentative identifications (Boon and de Leeuw, 1979; Schouten et al., 2000). These data suggest that IIIa-c and Va-c are the structures of the dominant steryl alkyl ethers in the Arabian Sea samples, i.e., different from the structure we tentatively proposed previously (Schouten et al., 2000) (Table 3).

A similar sequence of degradation experiments performed on the sterol alkyl ether fraction of ODP 1084 sediment yielded predominantly $\mathrm{C}_{27}-\mathrm{C}_{29} 3 \beta$-methylthio-5 $\alpha(\mathrm{H})$-steranes similar to the NIOP 309 sediment (Fig. 6b). The composition of the methylthioalkanes was dominated by $\mathrm{C}_{12}$ alkanes with one methylthiogroup. Surprisingly, no $\mathrm{C}_{10}$ alkyl chain with a methylthio-group was detected, as might have been expected from the presence of steryl alkyl ethers with a $\mathrm{C}_{10}$ alkyl chain. These compounds are rather volatile and may have been lost during work up. Mass spectral analysis revealed that the dominant fragment in the two most 


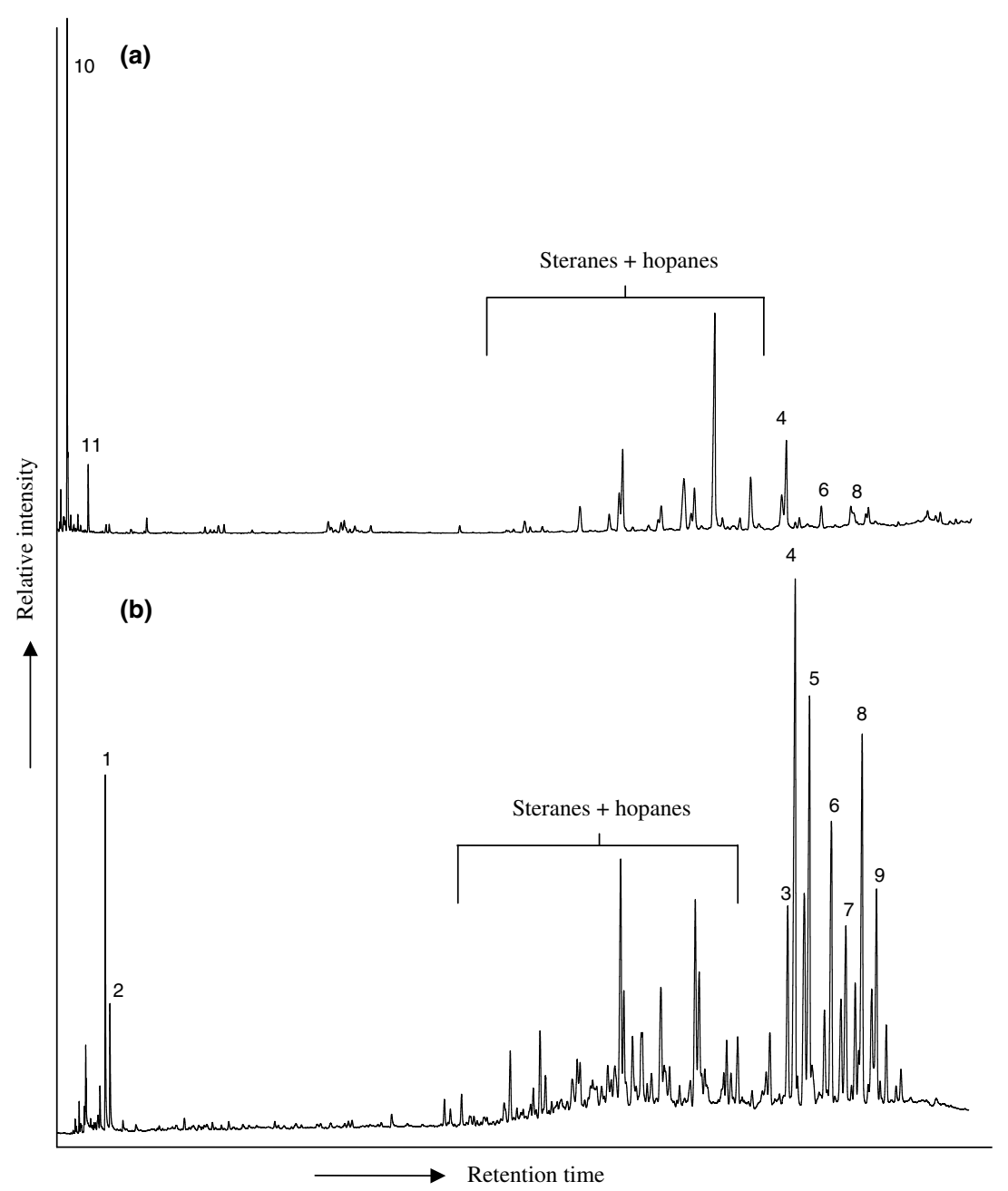

Fig. 6. Total ion current chromatograms of $\mathrm{HI} / \mathrm{NaSCH}_{3}$ degradation products of: (a) steryl alkyl ether fraction of NIOP 309 and (b) apolar fraction of ODP 1084. For compound identification see Table 3.

abundant $\mathrm{C}_{12}$ methylthioalkanes in the ODP 1084 sample was at $m / z 75$ and 89 , respectively. Based on comparison with mass spectra of authentic standards (Kohnen et al., 1991), this suggests that the methylthioalkanes are 2-methylthiododecane and 3-methylthiododecane, respectively. This means that the alkyl moieties in the steryl alkyl ethers in the ODP 1084 sediment were bound at positions $2^{\prime}$ and $3^{\prime}$ to the sterol moiety and not at the terminal position $1^{\prime}$ as proposed earlier (e.g., Boon and de Leeuw, 1979; Schefuß et al., 2001). These results lead to structures Ia-c and IIa-c for the dominant steryl alkyl ethers in ODP 1084.

\subsection{Synthesis of cholesteryl alkyl ethers}

To confirm the results of the degradation experiments, we synthesized some of the most abundant steryl ethers encountered in the ODP 1084 and NIOP 309 sed-

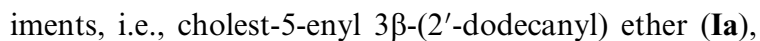

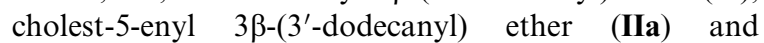

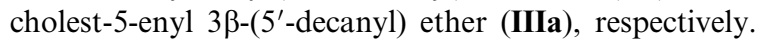
GC and GC-MS analysis of the product mixtures revealed that they all consisted of two closely eluting steryl alkyl ether isomers with identical mass spectra, but in varying ratios. Based on the synthetic procedure, it is likely that the two kinds of stereisomeric mixtures may have been formed: $3 \alpha$ - and $3 \beta-\mathrm{O}$-alkyl stereoisomers or $\mathrm{R}$ and $\mathrm{S}$ stereoisomers at the $\mathrm{C} 2^{\prime}, \mathrm{C} 3^{\prime}$ or $\mathrm{C}^{\prime}$ positions of the alkyl moieties of Ia, IIa and IIIa, respectively. To exclude the possibility that $3 \alpha$ - and $3 \beta-O$-alkyl stereoisomers were formed, we synthesized cholest-5-enyl $3 \beta$ (1'-dodecanyl) ether (IV) which does not possess a chiral centre in the O-alkyl side chain. GC and GC-MS analysis revealed only one peak with an identical mass spectrum to Ia and IIa. This suggests that the steryl alkyl ether isomers formed during synthesis are R/S 
Table 2

${ }^{13} \mathrm{C}$ and selected ${ }^{1} \mathrm{H}$ NMR data for cholest-5-enyl $3 \beta$-(2'-dodecanyl) ether (Ia) and cholest-5-enyl $3 \beta-\left(5^{\prime}\right.$-decanyl) ether IIIa

\begin{tabular}{|c|c|c|c|c|}
\hline \multicolumn{3}{|l|}{ Ia } & \multicolumn{2}{|l|}{ IIIa } \\
\hline $\mathrm{C}$ & ${ }^{1} \mathrm{H}$ & ${ }^{13} \mathrm{C}$ & ${ }^{1} \mathrm{H}$ & ${ }^{13} \mathrm{C}$ \\
\hline 1 & & $37.50 \mathrm{a}(\mathrm{s})$ & & $37.47(\mathrm{~s})$ \\
\hline 2 & & $29.75(\mathrm{~s})$ & & $29.37(\mathrm{~s})$ \\
\hline 3 & $3.18(1 \mathrm{H}, \mathrm{m})$ & $76.83,76.97(\mathrm{t})$ & $3.18(1 \mathrm{H}, \mathrm{m})$ & $77.28 \mathrm{a}(\mathrm{t})$ \\
\hline 4 & & $40.39(\mathrm{~s})$ & & $40.11(\mathrm{~s})$ \\
\hline 5 & & ca. $141.5(q)$ & & $141.54(\mathrm{q})$ \\
\hline 6 & $5.36(1 \mathrm{H}, \mathrm{d}, J=4.8 \mathrm{~Hz})$ & $121.23(\mathrm{t})$ & $5.36(1 \mathrm{H}, \mathrm{d}, J=4.9 \mathrm{~Hz})$ & $121.22(\mathrm{t})$ \\
\hline 7 & & $31.96(\mathrm{~s})$ & & $31.96(\mathrm{~s})$ \\
\hline 8 & & 31.91 & & $31.91(\mathrm{t})$ \\
\hline 9 & & $50.27(\mathrm{t})$ & & $50.25(\mathrm{t})$ \\
\hline 10 & & $36.88(\mathrm{q})$ & & $36.86(q)$ \\
\hline 11 & & $21.07(\mathrm{~s})$ & & $21.07(\mathrm{~s})$ \\
\hline 12 & & $39.82(\mathrm{~s})$ & & $39.80(\mathrm{~s})$ \\
\hline 13 & & $42.33(\mathrm{~s})$ & & $42.32(\mathrm{~s})$ \\
\hline 14 & & $56.82(\mathrm{t})$ & & $56.81(\mathrm{t})$ \\
\hline 15 & & $24.29(\mathrm{~s})$ & & $24.29(\mathrm{~s})$ \\
\hline 16 & & $28.23(\mathrm{~s})$ & & $28.23(\mathrm{~s})$ \\
\hline 17 & & $56.16(\mathrm{t})$ & & $56.13(\mathrm{t})$ \\
\hline 18 & $0.70(3 \mathrm{H}, \mathrm{s})$ & $11.86(\mathrm{p})$ & $0.70(3 \mathrm{H}, \mathrm{s})$ & $11.86(\mathrm{p})$ \\
\hline 19 & $1.02(3 \mathrm{H}, \mathrm{s})$ & $19.40(\mathrm{p})$ & $1.02(3 \mathrm{H}, \mathrm{s})$ & $19.41(\mathrm{p})$ \\
\hline 20 & & $35.77(\mathrm{t})$ & & $35.77(\mathrm{t})$ \\
\hline 21 & $0.94(3 \mathrm{H}, \mathrm{d}, J=6.5 \mathrm{~Hz})$ & $18.72(\mathrm{p})$ & & $18.71(\mathrm{p})$ \\
\hline 22 & & $36.20(\mathrm{~s})$ & & $36.18(\mathrm{~s})$ \\
\hline 23 & & $23.81(\mathrm{~s})$ & & $23.80(\mathrm{~s})$ \\
\hline 24 & & $39.52(\mathrm{~s})$ & & $39.51(\mathrm{~s})$ \\
\hline 25 & & $28.01(\mathrm{t})$ & & $28.01(\mathrm{t})$ \\
\hline 26 & & $22.56(\mathrm{p})$ & & $22.56(\mathrm{p})$ \\
\hline 27 & & $22.81(\mathrm{p})$ & & $22.82(\mathrm{p})$ \\
\hline $1^{\prime}$ & $1.13(3 \mathrm{H}, \mathrm{d})$ & $20.99(\mathrm{p})$ & & $14.15(\mathrm{p})$ \\
\hline $2^{\prime}$ & $3.50(1 \mathrm{H}, \mathrm{m})$ & $72.91(\mathrm{t})$ & & $22.97(\mathrm{~s})$ \\
\hline $3^{\prime}$ & & $37.42 \mathrm{a}(\mathrm{s})$ & & $27.88(\mathrm{~s})$ \\
\hline $4^{\prime}$ & & $25.82(\mathrm{~s})$ & & $34.95 b(\mathrm{~s})$ \\
\hline $5^{\prime}$ & & $29.00(\mathrm{~s})$ & $3.30(1 \mathrm{H}, \mathrm{m})$ & $77.40 \mathrm{a}(\mathrm{t})$ \\
\hline $6^{\prime}$ & & $29.65(\mathrm{~s})$ & & $34.70 \mathrm{~b}(\mathrm{~s})$ \\
\hline $7^{\prime}$ & & $29.65(\mathrm{~s})$ & & $25.25(\mathrm{~s})$ \\
\hline $8^{\prime}$ & & $29.65(\mathrm{~s})$ & & $32.14(\mathrm{~s})$ \\
\hline $9^{\prime}$ & & $29.34(\mathrm{~s})$ & & $22.67(\mathrm{~s})$ \\
\hline $10^{\prime}$ & & $31.96(\mathrm{~s})$ & & $14.15(\mathrm{p})$ \\
\hline $11^{\prime}$ & & $22.69(\mathrm{~s})$ & & \\
\hline $12^{\prime}$ & & $14.12(\mathrm{p})$ & & \\
\hline
\end{tabular}

Assignments of carbon and hydrogen atoms are based on comparison with literature data of 3ß-methoxysterols (D'Auria et al., 1992).

stereoisomers and that the original $3 \beta-\mathrm{O}$ configuration of cholesterol was preserved.

Further confirmation came from the ${ }^{1} \mathrm{H}$ and ${ }^{13} \mathrm{C}$ NMR analyses which were performed on the stereoisomeric mixture of sterol ethers formed by the synthesis

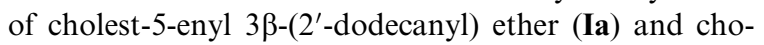

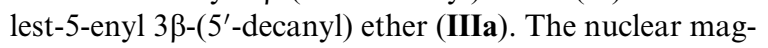
netic resonance (NMR) data (Table 2) are consistent with a $3 \beta-O-a l k y l$ configuration of the sterol ethers Ia and IIIa as the shift of the proton at C-3 (3.18 ppm, both for Ia and IIIa, Table 2) is in the same range as reported for 3 $\beta$-methoxysterols (3.05-3.16 ppm; D'Auria et al., 1992). In contrast, the shift for the proton at C-3 for $3 \alpha$-sterols is $0.5 \mathrm{ppm}$ downfield compared to that for
$3 \beta$-sterols (Kirk et al., 1990). In addition, the shift of the carbon atom C-3 (76.8-77.3 ppm, Table 2) is similar to that reported for $3 \beta$-tetrahydropyranyloxysterols ( 76 ppm; Szendi et al., 2000). The NMR data thus confirm the structures of Ia and IIIa, but they do not allow elucidation of the R/S stereochemistry of the steryl alkyl ethers.

The mass spectra of the synthetic compounds are identical to those of the sedimentary compounds (Fig. $2 \mathrm{a}-\mathrm{d})$. Co-injection of Ia and IIa with the ODP 1084 steryl alkyl ether fraction showed that the sedimentary compounds co-eluted with the later eluting stereoisomer of the synthetic standards (see above), indicating that only one stereoisomer is present in the sediments 
Table 3

Compounds identified after $\mathrm{HI} / \mathrm{NaSCH}_{3}$ degradation

\begin{tabular}{ll}
\hline Number $^{\mathrm{a}}$ & Compound \\
\hline 1 & 3-Methylthiododecane \\
2 & 2-Methylthiododecane \\
3 & $3 \alpha$-Methylthio-5 $\alpha$-cholestane \\
4 & $3 \beta$-Methylthio-5 $\alpha$-cholestane \\
5 & 3-Iodo-5 $\alpha$-cholestane \\
6 & 3 $\beta$-Methylthio-24-methyl-5 $\alpha$-cholestane \\
7 & 3-Iodo-24-methyl-5 $\alpha$-cholestane \\
8 & 3 $\beta$-Methylthio-24-ethyl-5 $\alpha$-cholestane \\
9 & 3-Iodo-24-ethyl-5 $\alpha$-cholestane \\
10 & 5-Methylthiodecane \\
11 & 4-Methylthiodecane \\
\hline
\end{tabular}

a Numbers refer to chromatogram in Fig. 6.

(Fig. 3b). Although we did not establish the configuration of the stereoisomers in the alkyl chain, the carbon skeleton of the sedimentary steryl alkyl ethers has now been unambiguously established. Co-injection of IIIa with the NIOP 309 fraction also confirmed the carbon skeleton of the dominant steryl alkyl ether as IIIa (Fig. 4, Table 1). Interestingly, co-injection of IIIa with the ODP 1084 steryl alkyl ether fraction showed that the steryl alkyl ethers with a $\mathrm{C}_{10}$ alkyl moiety were also attached at position 5 of the alkyl chain (Fig. 3(b)). In contrast, coinjection of Ia and comparison of relative retention times showed that Ia is only a minor isomer in the Miocene Monterey formation and that the dominant steryl alkyl ether with a $\mathrm{C}_{10}$ alkyl moiety eluted earlier, suggesting either a different position of the ether bond at the alkyl chain or, more likely considering the early retention time, that the alkyl chain is branched (Fig. 5a, Table 1). Remarkably, IV was not detected in the sediments.

It is clear from our work that the mass spectra of the steryl alkyl ether isomers allow the identification of the steroid moieties and the carbon number of the alkyl chains, but not the position of the ether bond in the alkyl chain (Fig. 2). Thus, it is not possible to determine the exact structure of steryl alkyl ethers based on mass spectrometry alone, and relative retention times are necessary as well. Therefore, pseudo-Kovats indices of the synthetic standards and steryl alkyl ethers in sediments are reported in Table 1.

\subsection{Origin of steryl alkyl ethers}

To the best of our knowledge, the sedimentary steryl alkyl ethers have not been found in any organisms; $3 \beta$ methoxysterols containing different $\mathrm{C}_{27}-\mathrm{C}_{29}$ sterol nuclei (mainly VIa-c) have been reported for a sponge from the Pacific Ocean (D'Auria et al., 1992). A methoxy methyl sterol ether, 24-methyl-5 $\alpha$-cholest-7-enyl 3 $\beta$-methoxymethyl ether (VII) has been reported to occur in a deep water marine sponge (Gunasekera et al., 1996) and was shown to be cytotoxic. However, steryl ethers with longer alkyl chains have, to the best of our knowledge, not been reported. Based on their occurrence in sediments with a high diatom input, Schouten et al. (2000) suggested diatoms as a direct biological source. However, analysis of 120 strains of predominantly marine diatoms, distributed over the phylogenetic tree on the basis of the 18S RNA gene (Sinninghe Damsté et al., 2004), did not reveal the presence of steryl alkyl ethers (Rampen S.W, Schouten S. and Sinninghe Damsté J.S., unpublished results). This means that the diatom producing steryl alkyl ethers has not yet been analysed or that other sources have to be invoked.

Analysis of a set of samples of particulate matter recovered with sediment traps and covering the full annual cycle at NIOP site 905, located near NIOP site 309 (Brummer et al., 2002), did not reveal the presence of steryl alkyl ethers. However, they were present in the core top sediment $(0-2.5 \mathrm{~cm})$ directly underneath the sediment trap at NIOP site 905 in a distribution similar to those at NIOP site 309 . Thus, herbivory processes may result in the production of steryl ethers in a similar way as has been suggested for steryl chlorins (Eckardt et al., 1992; Pearce et al., 1998). However, to the best of our knowledge the formation of ethers has not yet been shown to occur during ingestion of lipids. Furthermore, the distribution of free sterols from the same sediments is substantially different from that of the steroid moieties in the steryl alkyl ethers (cf. Schouten et al., 2000). However, this perhaps may also be caused by a selective preservation or selective incorporation of certain sterols as observed for steryl chlorins (Pearce et al., 1998; Talbot et al., 2000). Finally, since the alkyl chains are bound at specific positions to the sterols with stereochemical control, it seems more likely that biosynthetic pathways within a single type of organism are responsible for the production of steryl alkyl ethers. Further analysis of these compounds in different environments may shed more light on their distributions and origin.

\section{Acknowledgements}

Drs. J. Volkman, G. Wolff and P. Schaeffer provided comments which substantially improved this manuscript. We thank The Netherlands Indian Ocean Program and Dr. E. Koning, Dr. G.J. Brummer and T. van Weering (NIOZ) and Dr. E. Schefuß (NIOZ, now at University of Bremen) for making available the sediments and sediment trap material. M. Baas, J. Ossebaar and M. Kienhuis are thanked for analytical assistance and E. Hopmans for providing comments on a draft of the paper. Dr. M. Groen (Free University, Amsterdam) provided useful insights into the NMR analysis of the sterol alkyl ethers. This work was supported by grant BAR 5275 from the Dutch Technology Foundation STW. 


\section{Appendix}
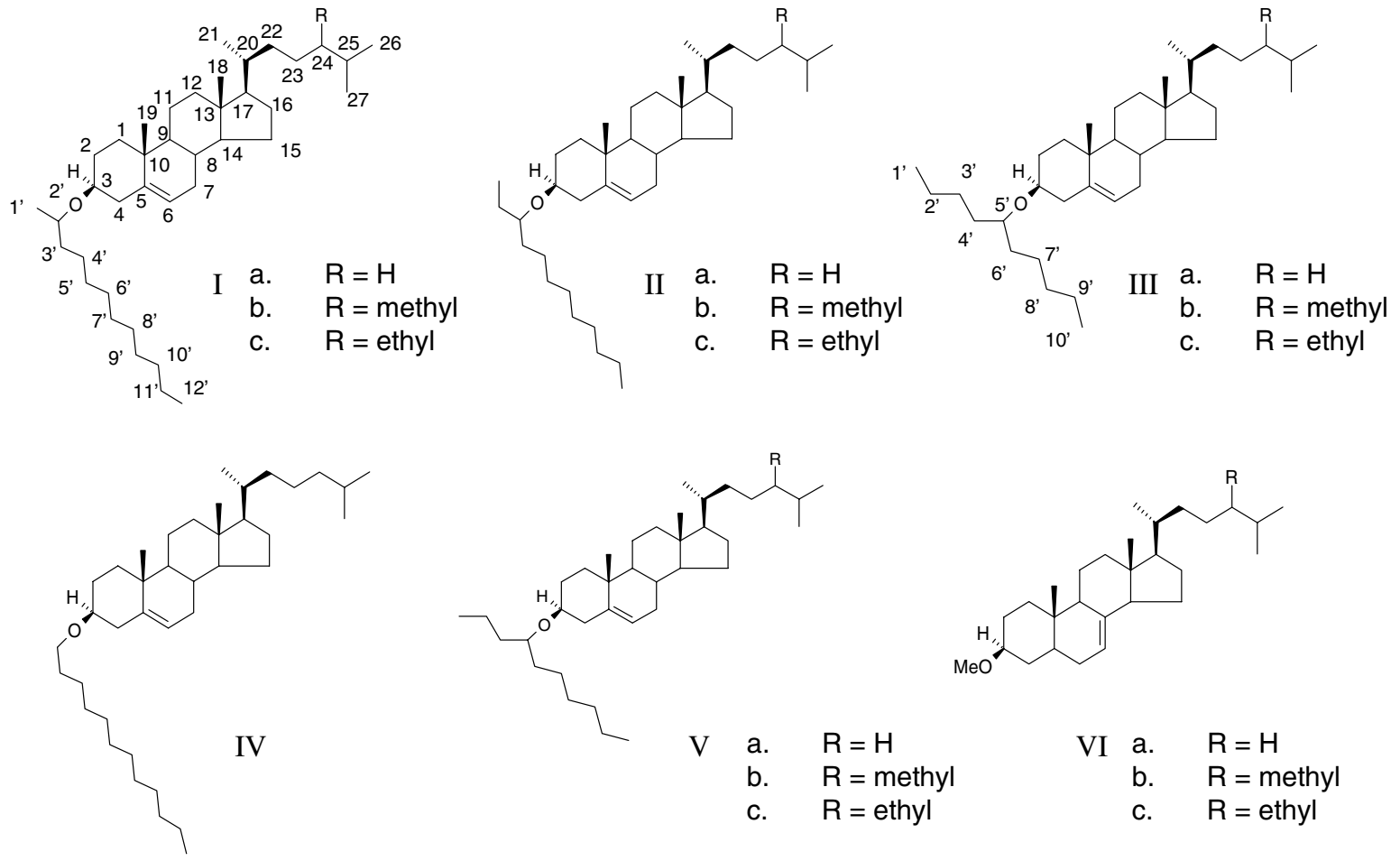

$$
\begin{array}{ll}
\text { a. } & R=H \\
\text { b. } & R=\text { methyl } \\
\text { c. } & R=\text { ethyl }
\end{array}
$$

$$
\begin{array}{rlr}
\text { VI } & \text { a. } & R=H \\
\text { b. } & R=\text { methyl } \\
\text { c. } & R=\text { ethyl }
\end{array}
$$<smiles>COCO[C@H]1CC[C@@]2(C)C(CC=C3C4CCC([C@H](C)CCCC(C)C)C4(C)CCC32)C1</smiles>

P.J.C., Volkman, J.K., 1980. The origin and fate of lipids in the Japan trench. In: Douglas, A.G., Maxwell, J.R. (Eds.), Advances in Organic Geochemistry 1979. Pergamon Press, Oxford, pp. 375-392.

\section{References}

Bills, C.E., McDonald, F.G., 1926. The catalytic formation of mixed cholesteryl ethers. Journal of Biological Chemistry 72, 1-19.

Boon, J.J., de Leeuw, J.W., 1979. The analysis of wax esters, very long mid-chain ketones and sterol ethers isolated from Walvis Ridge diatomaceous ooze. Marine Chemistry 7, 117132.

Brassell, S.C., 2003. Molecular proxies of paleoenvironments: sterol ethers in Valanginian sediments and paleoproductivity in the Pacific. Abstract International Meeting on Organic Geochemistry, GEOSFERA, Krakow, Poland

Brassell, S.C., Comet, P.A., Eglinton, G., Isaacson, P.J., McEvoy, J., Maxwell, J.R., Thomson, I.D., Tibbetts,

Brummer, G.J., Kloosterhuis, H.T., Helder, W., 2002. Monsoon-driven export fluxes and early diagenesis of particulate nitrogen and its $\delta^{15} \mathrm{~N}$ across the Somalia margin. In: Clift, P.D., Kroon, D., Gaedicke, C., Craig, J. (Eds.), The tectonic and climatic evolution of the Arabian Sea region, Geological Society, London, Special Publications 195, pp. 353-370

D’Auria, M.V., Paloma, L.G., Minale, L., Riccio, R., Debitus, C., Levi, C., 1992. Unique 3ß-O-methylsterols from the Pacific sponge Jereicopsis graphidiophora. Journal of Natural Products 55, 311-320.

Eckardt, C.B., Pearce, G.E.S., Keely, B.J., Kowalewska, G., Jaffe, R., Maxwell, J.R., 1992. A widespread chlorophyll transformation pathway in the aquatic environment. Organic Geochemistry 19, 217-227. 
Funasaki, H., Gilbertson, J.R., 1968. Isolation and identification of cholesteryl alkyl ethers from bovine cardiac muscle. Journal of Lipid Research 9, 766-768.

Gunasekera, S.P., Kelly-Borges, M., Longley, R., 1996. A new cytotoxic sterol methoxymethyl ether from a deep water marine sponge Scleritoderma cf paccardi. Journal of Natural Products 59, 161-162.

Isaacs, C.M., Rullkötter, J., 2001. The Monterey Formation: from Rocks to Molecules. Columbia University Press, New York, pp. 553.

Kirk, D.N., Toms, H.C., Douglas, C., White, K.A., Smith, K.E., Latif, S., Hubbard, R.W.P., 1990. A survey of the high-field H-1-nmr spectra of the steroid-hormones, their hydroxylated derivatives, and related-compounds. Journal of the Chemical Society, Perkin Transactions 2, 1567-1594.

Kohnen, M.E.L., Sinninghe Damsté, J.S., Kock- van Dalen, A.C., de Leeuw, J.W., 1991. Di- or polysulphide-bound biomarkers in sulphur-rich geomacromolecules as revealed by selective chemolysis. Geochimica et Cosmochimica Acta 55, 1375-1394.

Marlow, J.R., Farrimond, P. Rosell-Melé, A., 2001. Analysis of lipid biomarkers in sediments from the Benguela Current coastal upwelling system (Site 1084). Initial results. In: Wefer, G., Berger, W.H., Richter, C. Proceedings of the Ocean Drilling Program, Scientific Results. 175 (Chapter 5).

Pearce, G.E.S., Harradine, P.J., Talbot, H.M., Maxwell, J.R., 1998. Sedimentary sterols and steryl chlorin esters: distribution differences and significance. Organic Geochemistry 28, 3-10.

Schefuß, E., Versteegh, G.J.M., Jansen, J.H.F., Sinninghe Damsté, J.S., 2001. Marine and terrigenous lipids in Southeast Atlantic sediments (Leg 175) as palaeoenvironmental indicators: initial results. In: Wefer, G., Berger, W.H., Richter, C. Proceedings of the Ocean Drilling Program, Scientific Results. 175 (Chapter 10).

Schouten, S., Hoefs, M., Koopmans, M., Bosch, H.-J., Sinninghe Damsté, J.S., 1998. Structural characterization, occur- rence and fate of archaeal ether-bound acyclic and cyclic biphytanes and corresponding diols in sediments. Organic Geochemistry 29, 1305-1319.

Schouten, S., Hoefs, M.J.L., Sinninghe Damsté, J.S., 2000. A molecular and stable carbon isotopic study of lipids in Late Quarternary sediments from the Arabian Sea. Organic Geochemistry 31, 509-521.

Schouten, S., De Loureiro, M.R.B, Sinninghe Damsté, J.S., de Leeuw, J.W., 2001. Molecular biogeochemistry of Monterey sediments (Naples beach, USA) I: distributions of hydrocarbons and organic sulphur compounds. In: Isaacs, C.M., Rullkötter, J. (Eds.), The Monterey Formation: from Rock to Molecule. Columbia University Press, pp. 150 174.

Sinninghe Damsté, J.S., Muyzer, G., Abbas, B., Rampen, S.W., Massé, G., Allard, W.G., Belt, S.T., Robert, J.-M., Rowland, S.J., Moldowan, J.M., Barbanti, S.M., Fago, F.J., Denisevich, P., Dah 1, J., Trindade, L.A.F., Schouten, S., 2004. The rise of the rhizosolenoid diatoms. Science 304, 584-587.

Szendi, Z., Forgo, P., Kover, K.E., Sweet, F., 2000. High-field NMR studies of 3 beta-tetrahydropyranyloxy steroids. Steroids 65, 415-422.

Talbot, H.M., Head, R.N., Harris, R.P., Maxwell, J.R., 2000. Discrimination against 4-methyl sterol uptake during steryl chlorin ester production by copepods. Organic Geochemistry $31,871-880$.

Volkman, J.K., 1986. A review of sterol markers for marine and terrigenous organic matter. Organic Geochemistry 9, 83-99.

Volkman, J.K., Barrett, S.M., Blackburn, S.I., Mansour, M.P., Sikes, E.L., Gelin, F., 1999. Microalgal biomarkers: a review of recent research developments. Organic Geochemistry $29,1163-1180$.

Van Weering, T.C.E., Helder, W., Schalk, P., 1997. The Netherlands Indian Ocean expedition 1992-1993, first results and an introduction. Deep Sea Research Part II 44, $1178-1193$ 